\title{
Popular Music Studies and Ethnomusicology in Australasia
}

\author{
Dan Bendrups \\ Griffith University \\ d.bendrups@griffith.edu.au
}

\begin{abstract}
A characteristic of the field of popular music studies in Australia and New Zealand (Australasia) is the strong and enduring presence of ethnomusicology and allied ethnographic approaches to popular music research in this region. In Australasia, ethnomusicology offers popular music researchers the opportunity to engage in a meaningful and direct way with a range of musical practices by Indigenous and migrant performers. Meanwhile, popular music studies provides ethnomusicologists with a way of demonstrating that they are interested in more than just traditional or ancestral musical practices. This article will provide a history of the interdisciplinary relationship between ethnomusicology and popular music studies in Australasia, and will examine the role of Indigenous and migrant music research in fostering links between these two disciplinary fields.
\end{abstract}

Keywords: Ethnomusicology, Popular Music, Australia, New Zealand

\section{Introduction}

This paper presents a history of engagement between ethnomusicology and popular music studies in Australia and New Zealand (Australasia), and is intended as a contribution, albeit not a definitive one, towards the aim of exploring the treatment of popular music studies in different cultures and contexts. Australasia is an interesting choice for inclusion in such a discussion, as it is simultaneously inside and outside the largely Anglocentric and North Atlantic focus points of global popular music production and consumption: 'inside' because of enduring legacies of colonialism and contact with the UK and the USA; 'outside' because, despite their positioning within the 'Anglosphere', Australia and New Zealand nevertheless belong to a different geography, one that places them at the antipodes of Europe, on the doorstep of Asia and embedded within the Pacific. ${ }^{1}$ This positioning within the Asia-Pacific region creates opportunities for research in which local and regional performance cultures, particularly Indigenous cultures, are foregrounded. ${ }^{2}$

My focus on ethnomusicology, which is just one of the many scholarly interfaces for popular music research in Australasia, is primarily a reflection of the fact that Australasian ethnomusicologists have played a prominent role in engaging with the music of the Asia-Pacific region. However, it is also a direct response to Philip Tagg's recent characterisation of ethnomusicology as "[often] a subdiscipline under musicology...marginalised as a sort of exotic aural exception to the Central European scribal rule" (Tagg 2011: 8). While this observation may hold true in Tagg's experience, and while there is a history of epistemic tension between musicology and ethnomusicology in Australasia (Wild 2006), the work of Australasian ethnomusicologists and their engagement with 'the popular' reflects a regionalism that 
is different to northern-hemisphere contexts, possessing, in the words of Stephen Wild, a 'distinctive voice' (Wild 2006), and therefore worthy of some exploration. Tagg's characterisation evokes a shadow of the 'Euroamericentric' bias (Loza 2006) that has been the subject of much reflection and critique within ethnomusicology. Steven Loza attributes this bias to an overreliance on ideas and practices generated in the US and Europe, which he describes as embodiments of academic hegemony and chauvinism of intellectual dominance (2006: 361). Certainly, for ethnomusicologists 'doing' popular music in Australasia, there are lessons to be learned from this critique, and this article therefore deliberately foregrounds research published in Australia and New Zealand by local and regional scholars.

In this article I seek to demonstrate that the relationship between ethnomusicology and popular music studies in Australasia, and the unique research character and perspectives that this enables, produces a culture of scholarship that has begun to transcend, in its own ways, the sort of "epistemic inertia" described by Tagg (2011: 78). ${ }^{3}$ This research culture is, in my view, a product of engagement with three domains that are particular to the Australasian context: Indigenous musics of Australia and New Zealand, migrant community musics, and Indigenous musical practices of the wider Pacific region of Oceania. These three frames of reference largely define the scope of Australasian ethnomusicology in the twenty-first century (relatively fewer Australasian ethnomusicologists are involved in research projects in Africa, Europe or the Americas) and they therefore play a direct role in defining ethnomusicology in relation to popular music studies in this part of the world. The articulation of these reference points communicates a generalised experience of what it means to be an Australasian ethnomusicologist working in popular music studies.

While ethnomusicology is not the focus of Tagg's recent IASPM Journal article, and while no self-identifying ethnomusicologists figure amongst the founding fathers (all male) of IASPM, there is little doubt that ethnomusicology and popular music studies are fellow travellers. For one thing, they both largely deal with musics that fall outside the Euroamericentric art music canon. For another, the social activism inherent in the early goals of IASPM (Smith 2011) was foreshadowed as one for the four pillars of the 'anthropology of music' described by Allan P. Merriam decades earlier (Merriam 1964: 8-9). Both fields are also grounded in the same sort of 'insider' appreciation of music, described by Bruce Johnson as "an affinity between popular music studies and ethnomusicologists. Both are permanently engaged in field work" (Johnson 2007: 39). Indeed, the (US-centric) Society for Ethnomusicology has a history of engagement with 'the popular', as in the example of the 1995 symposium on 'technoculture' initiated by René Lysloff and Leslie Gay:

Our purpose in arguing for an ethnomusicology of technoculture was to break from past conventions of examining only folkish or high art "traditions" of music, on the one hand, and to go beyond discussing the music "industry" in the study of popular culture, on the other (...) The ethnographic Other is now fully plugged in, and the ethnomusicologist is no longer the only person in the field with high-tech equipment. (2003: 3)

In the Australasian context, the most significant factor in ethnomusicologists' engagement with popular music is the fact that the musicians from communities with whom they work have thusly engaged with or adapted global popular music elements and equipment to their own cultural ends. Once referred to (somewhat negatively) in ethnomusicology as 'acculturation', Australasian ethnomusicologists have long realised the cultural significance of such processes, as articulated in 1981 by New Zealander Allan Thomas in relation to contemporary musical practices in Oceania:

(...) there are distinctive musical procedures at work in the performance of Oceanic acculturated musics that warrant the attention of ethnomusicologists. These procedures are not those of the parent music - the European music from which the tunes appear to be borrowed, nor are they purely the procedures of traditional music either. They are in 
some sense a "pidgin" musical language - simplifying, recombining and developing elements of both parent systems. (1981: 183-84)

Finally, while this article is intended as a response to the questions raised by Tagg (2011), it sidesteps the four-theme framework that he outlines, and it is not specifically intended as a history of IASPM in Australasia. With regard to the former, Tagg's delineation of interdisciplinarity, interprofessionalism, epistemic inertia and invisible music as four core issues serves (in my reading) as a way of understanding popular music studies across a range of possible geographic and conceptual locations, whereas this article is specifically concerned with unpacking just one of these: the discipline of ethnomusicology and its relationship to popular music studies in Australasia. With regard to the latter, and bearing in mind that IASPM is not necessarily the locus of all popular music studies, excellent histories of the IASPM-ANZ regional chapter of the association and its significance for music scholarship have already been provided by Graeme Smith (2011) and Philip Hayward (2007). Where Graeme Smith writes from the perspective of someone involved in developing popular music studies from the very beginning, my own engagement with this field occurred later, in the late 1990s, at a point in time in which a degree of scholarly traction had already been achieved in popular music studies, and in which popular music was consolidated as an area of study in many Australasian institutions, ${ }^{4}$ albeit with some particular exceptions. ${ }^{5}$ My narrative frame, which focuses on the mid-1990s, follows on from Smith's, and describes initiatives built on the foundations laid by the first generation of Australasian popular music scholars. ${ }^{6}$

\section{Ethnomusicology, Musicology and Popular Music Studies in the Australasian Context}

Within Australia and New Zealand, the contribution of ethnomusicologists to the development of popular music studies largely reflects the position of ethnomusicology in relation to its most significant 'others': musicology and anthropology. While key sociologists, media studies researchers and cultural studies researchers have played important roles in developing the discipline of popular music studies in Australasia, there has been little historical interaction between sociology, cultural studies and media studies on the one hand, and ethnomusicology and musicology on the other (and where interaction has occurred, it has often been via popular music research topics). Most Australian ethnomusicologists have a musical background, albeit often in an area different or tangential to their sites of research. While some well-established Australian ethnomusicologists have benefited from an anthropological training, it is unusual to find ethnomusicologists embedded within anthropology departments in Australian universities. The situation is a little different in New Zealand, where the University of Auckland considers ethnomusicology as a sub-discipline of anthropology, ${ }^{7}$ and where the university's most successful popular music course is provided by an ethnomusicologist within the anthropology department.

For the most part, ethnomusicological engagement with popular music has occurred separately to the negotiation of alliances and tensions between ethnomusicology and musicology in metropolitan conservatoria and music schools. The nature of the relationship between musicology and ethnomusicology is a subject of substantial debate, with polarised responses. On the one hand, there are those scholars who assert that these two cognate disciplines have a unified history in Australasia that is relatively free from Eurocentrism. On the other hand, some ethnomusicologists have been critical of the perceived Eurocentrism of musicology, and have pointed to the exclusion of popular music studies in musicology to assert this. These positions will be discussed further below.

The notion of disciplinary cohesion between musicology and ethnomusicology may be perceived in the attitudes and influence of the scholars who established and fostered Australasian musicology in the 1950s and 1960s. One significant contribution 
in this vein is that of former University of Otago lecturer and University of Sydney professor Peter Platt, a historical musicologist who helped to build ethnomusicology in both New Zealand and Australia. Platt's influence is reflected in his role in encouraging the ethnomusicological research of Mervyn McLean and Allan Marett in Māori and Aboriginal music respectively. As Marett comments, Platt was convinced that musicologists should be conversant in the music of the place where they work (Marett 2008), and for Australia and New Zealand this implicitly included Indigenous musics. This meant engaging deeply and directly with Aboriginal and Māori musicians in ways that would simply not have been possible in European contexts, and which were usually the preserve of anthropologists or folklorists in North American contexts.

In a poignant testimonial, the posthumous publication of Platt's 2000 address to the Musicological Society of Australia conference in the journal Musicology Australia reveals a sense of his perspective, and furthermore, articulates his desire that music be appreciated not just for its aesthetic qualities, but for its capacity to contribute to the understanding of the human mind. In other words, to demonstrate that music research can contribute to knowledge more than just an understanding of music, but an understanding of human endeavour. In that paper, Platt revealed his long interest in seminal American ethnomusicologist and anthropologist Allan Merriam's 'anthropology of music' (Platt 2000: 3), describing Merriam's three analytical constructs conceptualisation, behaviour, and sound - as an ideal guiding principle for the contemplation of all music.

Australasian ethnomusicology was established on these foundations, with a generation of scholars (including Trevor Jones, Catherine Ellis, Alice Moyle, and subsequently Stephen Wild, Mervyn McLean, Richard Moyle, Allan Marett and others) establishing frameworks for the incorporation of Indigenous musics into the musicological mainstream. Many of these scholars received specialist training in Europe or the United States, thus linking Australasian academics to these larger centres. Stephen Wild once described this training as "invaluable, exhilarating and lifeforming" (2006: 351). Scholars such as Margaret Kartomi and Allan Thomas extended this coverage into the traditional musics of surrounding Asia-Pacific countries, as well as migrant communities within Australasia, and they strongly influenced (or directly supervised) the generation of ethnomusicologists currently occupying senior positions in Australasian universities.

In Australia, in the 1980s, many ethnomusicologists focussed their attention on musics that reflected the new social and cultural landscapes of urban Australia following World War Two, with expanded immigration, and (in the 1970s) the wholesale adoption of multiculturalism as government policy. Writing in 1984, Margaret Kartomi produced an article for the International Musicological Society journal Acta Musicologica, in which she summarised a history (1979-1984) of music research at Australian universities, divided into four categories: ethnomusicology, historical musicology, systematic musicology, and 'others'. On the topic of ethnomusicology, Kartomi stated, "In view of Australia's geography, the multi-cultural composition of her population, and the availability of sources, it is not surprising that a good deal of her musicological research has been devoted to the non-Western and folk musics practiced in and near the country" (1984: 112).

Kartomi offered a construction of Australian musicology that was reflective of regional sensibilities, necessities and interests. While calling for more research on Aboriginal music, she also called for the recognition of Australia's own art music history, which she considered to have been neglected by scholarship. In her conclusion, Kartomi raised the issue of disciplinary segregation (a point problematised at length by Tagg [2011]), stating:

A problem experienced in Europe and North America, but so far averted in Australia, is that of splits between ethnomusicologists, historical musicologists, and others. The conscious effort has continually been made when planning national and regional 
meetings to choose themes of wide interest and applicability and to encourage contributions by all kinds of musicologists. Thus, ethnomusicologists have played no smaller a role than have other kinds of musicologists in the MSA [Musicological Society of Australia], which has to date enjoyed a remarkable degree of unity. In addition, most tertiary music institutions have recently come to regard as essential for the implementation of their educational aims the inclusion of some courses in non-Western musics, along with courses in historical and systematic musicology. (1984: 144)

There is no mention of popular music in Kartomi's article, which is focussed on the period predating the institutional establishment of popular music studies in Australasia. However, Kartomi had by this stage already contributed to the regional development of popular music studies, reflected in coursework that she devised for Open University of Australia and Monash University courses, and in a seminal article, published in the journal Ethnomusicology, in which she argued against the prevailing and somewhat colonialist tendency in ethnomusicology to view acculturated music cultures, in which non-Western traditional musics, performers or practices are combined with Western commercial music influences, with disapproval (1981: 227). At this time, Kartomi was also supervising doctoral students and mentoring academic colleagues who would soon become key contributors to Australian popular music studies, particularly in the context of folk and migrant musics. Indeed, Graeme Smith cites Kartomi's academic leadership as a factor in the development of his own engagement with popular music studies and IASPM:

Margaret Kartomi... had attended a musicology conference [in 1984] in Europe, and she was invited to a lecture tour of Sweden by the Swedish musicologist Jan Ling from the University of Gothenburg.... In Europe she met Ling's associate and ex-PhD student Phillip Tagg, and she returned to Australia with a copy of Tagg's thesis on the theme from the TV detective show Kojak as well as some IASPM material. Being a compulsive joiner, I clipped the coupon and sent it off with my international money order, as did another of her students... (Smith 2011: 126)

Smith describes this mid-1980s period of engagement with popular music as a convergence of socio-musical activism and institutionalisation, with protagonists from various professional spheres and an ethos of collaboration. He characterises the involvement of ethnomusicologists within this as follows:

Soon we were joined by a number of other ethnomusicology postgraduates from Monash including Aline Scott-Maxwell, active member and scholar ever since. Aline and I were at this time part of a group of postgraduates at Monash who were interested in the contemporary moves within ethnomusicology to question its colonialist legacy and to take on some of the directions of the new critical anthropology... as postgraduate students, we and the other members had relatively slight institutional ties to the university system. However it was the very absence of any institutional interest in popular music studies which stimulated us to establish links with something we saw as an international movement. (Smith 2011: 126)

As Smith observes, this movement eventually became more institutionalised in the 1990s (2011: 129) with the establishment of a number of new popular music courses and departments, and the consolidation of IASPM-ANZ into a body with broad institutional membership and annual academic conferences. The IASPM-ANZ branch was established in 1984, but while it held various small events in Melbourne, it did not have a dedicated conference until 1992, following the infusion of a new group of researchers, many based at Sydney institutions, who expanded the research community for popular music studies and fostered local and regional affiliations. Since that time, the organisation has hosted conferences almost every year, including an international IASPM conference in Sydney in 1999, as well as publishing peer reviewed conference proceedings on a regular basis. A cursory overview of the contents of these proceedings reveals consistently strong participation from ethnomusicologists and other ethnographers of Indigenous, migrant, and Asia-Pacific region music cultures, accounting for roughly a third of the papers published. 
Table 1: Indigenous, migrant and Asia-Pacific music content in IASPM-ANZ conference proceedings. $^{8}$

\begin{tabular}{|l|l|l|l|l|l|}
\hline Year & Indigenous & $\begin{array}{l}\text { Migrant and } \\
\text { multicultural }\end{array}$ & $\begin{array}{l}\text { Asia- } \\
\text { Pacific }\end{array}$ & $\begin{array}{l}\text { Total in } \\
\text { volume }\end{array}$ & $\begin{array}{l}\text { \%thno- } \\
\text { musicological }\end{array}$ \\
\hline 1998 & 7 & 2 & 0 & 26 & $35 \%$ \\
\hline 2001 & 1 & 4 & 1 & 25 & $24 \%$ \\
\hline 2005 & 0 & 3 & 1 & 11 & $36 \%$ \\
\hline 2007 & 1 & 4 & 5 & 32 & $31 \%$ \\
\hline 2008 & 0 & 4 & 1 & 18 & $28 \%$ \\
\hline 2009 & 0 & 1 & 2 & 15 & $20 \%$ \\
\hline 2010 & 1 & 1 & 3 & 28 & $18 \%$ \\
\hline
\end{tabular}

Subsequent to the consolidation of IASPM-ANZ, and perhaps strengthening it, was the mid-1990s establishment of popular music courses and departments at Australian universities. Some of these engaged quite directly with ethnomusicological research imperatives, albeit often in isolation from ethnomusicologists (and musicologists) in established music conservatoria. A case in point is the Department of Contemporary Music Studies (DCMS) established at Macquarie University by Philip Hayward in 1999. This initiative built on Hayward's established profile in popular music, represented especially through the journal Perfect Beat: The Pacific Journal of Research into Contemporary Music and Popular Culture, which he founded in 1992. It is interesting to note that this journal, from the outset, was oriented towards not just Australasian popular music, but that of the wider Pacific region:

The second issue of the journal (v1n2) was published in January 1993 and explicitly addressed the musical ramifications of IYWIP [UNESCO's International Year of the World's Indigenous Peoples] and debates around world music in its editorial; its paired debate on aspects of the commercial success of Yothu Yindi's Treaty single (...) its two articles on Taraban (...) three further articles on Aboriginal rock (...) And an extraAustralian article on the development of the 'Jawaiian' genre in Hawai'i. (Hayward 2007: 8)

From 1999 onward, Macquarie's DCMS became a locus of Pacific-focussed popular music research, consolidated around the journal and a commercially-oriented record label, Coral Music, intended as a means of providing islander musicians with access to the record industry as a form of fieldwork reciprocity. ${ }^{9}$ Hayward credits the guiding influence of acclaimed US anthropologist Stephen Feld as a factor in both the Pacific focus of the department and the journal, and the emphasis on ethnographic engagement (and reciprocity) with musicians and communities as a fundamental basis for much of the research undertaken there (personal communication, 7 September 2012).

At the turn of the twenty-first century, commentators from across musicological, ethnomusicological and popular music studies were conversant with each other's fields and interests, but not always seeing eye-to-eye. On the one hand, commentators such as Monash University's Craig de Wilde, a historical musicologist and popular music historian, expressed little concern regarding popular music's 'place' and recounted scant resistance to popular music topics within Australasian musicology:

$(\ldots)$ to suggest that there is no room in the academic musicological discipline now for the study of popular music simply does not hold true when this viewpoint is placed under any scrutiny. (...) On the other hand, to suggest that historical musicology has nothing to offer popular music research is equally invalid. For example, exactly the "dots-and-lines-onthe-page" analysis that many have criticised as being inappropriate for popular music research is becoming highly significant in some circles. (2000: 8)

On the other hand, Hayward perceived ongoing resistance to popular music within the musicology/ethnomusicology establishment, going as far as to describe these disciplines as, essentially, petrified, for their lack of engagement with commercially constructed musics (Hayward 2000: 182). In doing so, Hayward was equally critical of 
popular music researchers working in avant-garde, fringe and world areas, as he was of traditional music-focussed ethnomusicology and Eurocentric musicology, even placing his own prior research in the firing line. His article culminates in the articulation of a 'great divide' in Australasian music research, in which commercially-constructed forms of popular music remained excluded from institutional music research.

The notion of a great divide was subsequently rearticulated by ethnomusicologist Stephen Wild in his 2005 address to the Society for Ethnomusicology conference, where he lamented what he perceived as the historical lack of engagement in Australian ethnomusicology and musicology with popular music research - a disjuncture he attributed to the historical dominance of musicological models in the Australian tertiary education system: "Australian ethnomusicology has been dominated by a musicological approach which has fostered the analysis of musical sound but has been inhospitable to the study of popular music" (2006: 351). It was also a prominent theme in the reflections of popular music researchers who contributed to a special issue of the journal Perfect Beat in 2007. This issue marking the journal's fifteenth anniversary included a forum of comments from Australian popular music researchers, all reflecting on the journal's achievements and significance (Johnson 2007). Much of this discussion ended up centring on the institutionalisation of popular music studies, its development as a discipline, and the challenges faced by popular music scholars in the early years of establishing the field. To ignore this history is to diminish the efforts of those involved in first advocating for popular music to be researched within the academy. Within this discussion, however, a number of commentators referred to ethnomusicology as a constructive and positive force in the development of popular music studies (Johnson 2007: 15-29).

The notion of a 'great divide' has, however, been directly countered on at least one occasion. Writing in 2002, popular music ethnographer Robin Ryan used the occasion of the Sydney Olympics (in 2000) as an entry point to discussing the constructive relationship between popular music studies, musicology and ethnomusicology (Ryan 2002). In her article, Ryan contests Hayward's assertion that the inherent differences between the disciplines are entrenched across generational lines, arguing instead that contemporary music researchers understand the way that the three disciplines dovetail into one another (Ryan 2002: 172-73), and that it is these points of overlap that suggest the future directions for music research. She articulates this position by invoking Mark Slobin's assertion that cultural flow occurs "as much between the cracks as through the accepted channels" (Ryan 2002: 165).

A decade on from these remarks, Ryan's prediction of disciplinary overlaps becoming a dominant mode of music research in Australasia has largely been borne out. At the University of Otago, a Mahler specialist teaches popular music performance (Downes 2011). At Griffith University, a music education specialist engages with remote Indigenous youth through popular music production and composition (Bartleet 2012). At Macquarie University, the now aggregated Department of Media, Music and Cultural Studies offers the (rather traditional) ethnomusicological pursuit of Indonesian gamelan. Such overlaps are a normalised part of the contemporary Australasian music student's university experience. At the disciplinary level, a regional committee for the ethnomusicology-focussed International Council for Traditional Music was founded in 2009 with an executive committee in which all of the region's existing music research organisations (the MSA, the New Zealand Musicological Society [NZMS], and IASPMANZ) were represented. This was the first time that all of these organisations had been formally aligned in this way. For the most part, individual ethnomusicologists have followed suit, engaging with popular music across various domains including film, record production, festivals, community music groups, local and regional music industries, and other domains. These engagements provide an answer to Wild's concerns about ethnomusicology's lack of engagement with popular music, as well as Hayward's accusations of disciplinary petrification. In the discussion that follows, I draw 
attention to the three domains in which this engagement best demonstrates the 'unique voice' of Australasian ethnomusicology: Indigenous music, migrant music, and music in the wider Pacific.

\section{Popular Music in Indigenous Contexts}

As noted earlier, engagement with Indigenous musics provided the foundation for ethnomusicology in both Australia and New Zealand. On the one hand, this reflected scholars' perceptions that these traditions were in danger of disappearance or in need of documentation for cultural heritage purposes. On the other hand, however, it also reflects the reality that both Australia and New Zealand are nations superimposed upon existing Indigenous communities and frameworks, and that these communities did not simply cease to exist with the creation of new nation states by settler societies. Indigenous responses to this colonial legacy across these two countries have taken numerous forms, including, since the 1970s, engagement with popular music as a means of making cross-cultural contact, of generating a mainstream space for Indigenous cultural expression, and more recently, a means of engaging the interests of modernised and urbanised Indigenous youth.

Such initiatives have directly informed the experiences of ethnomusicologists (and others) working with Indigenous communities, and are often reflected in ethnomusicological writing. Mervyn McLean, with reference to the entire colonial period in New Zealand, acknowledges that 'traditional' and 'new' songs exist side by side in Māori music, without one threatening the existence of the other (1999: 437), and, with reference to broader Polynesia, that guitar-based string band music has led quite seamlessly to the introduction of electric guitars and other rock-derived instrumentation (1999: 448). More recent developments, such as the growth of a vibrant hip hop scene in New Zealand (incorporating especially Māori and Pacific Islander performers) fall within ethnomusicological and anthropological discourses (Zemke-White 2002) as well as broader popular culture scholarship (Mitchell 1996; Pearson 2004).

In Australia, meanwhile, scholarly engagement with Indigenous popular music has ranged from the analysis of commercial recordings (Dunbar-Hall 2001) through to major projects based specifically on the production of commercial recordings for cultural heritage purposes (Neuenfeldt 2007). One landmark early publication in this field was Karl Neuenfeldt's edited volume on didjeridu (Neuenfeldt 1997), which canvassed traditional performance contexts through to the incorporation of this iconic instrument in popular music, written by a range of contributors from different disciplines. An earlier work, Marcus Breen's edited volume Our Place, Our Music (1989) provided an important space for Indigenous music within the still-emerging field of popular music studies. Importantly, these works include Indigenous voices and perspectives alongside the work of non-Indigenous researchers.

More recent ethnomusicological and anthropological research with Indigenous popular music groups in Arnhem Land and Central Australia has affirmed Indigenous engagement with popular music as a continuation of traditional practices. These (often long-term) ethnographic research projects have enabled researchers to gain greater understanding of how Indigenous culture bearers view the nexus between traditional and popular musics. For example, as Aaron Corn notes with regard to his Arnhem Land research:

It was apparent to me that the adoption of transnational styles such as rock, country and reggae, and their associated instrumentation and technologies through the formation of popular bands had unquestionably furnished Arnhem Landers with musical templates that were readily amenable to the incorporation of local content drawn from their own performative traditions. (2002: 15)

Similarly, in her research dealing with popular music and masculinity in Indigenous contexts, Åse Ottosson $(2010,2009)$ has asserted the capacity for popular music 
genres such as country, rock and reggae to act as catalysts for cross cultural mediation, both between performers and audiences, and between Indigenous and nonIndigenous performers and other professionals:

In their musical life, the Central Australian Aboriginal men continuously engage with ideas, practices and values from varying sources and sociocultural formations. Such intercultural engagements and experiences become embedded, in layers upon layers, as the men reiterate them in their day-to-day practices and musical expressions. The ways in which they articulate such mediated forms of being male and blackfella differ from one sociomusical setting to the next. (Ottosson 2009: 99-100)

Significantly, these research projects have eventuated not from a scholarly stance concerned with fostering popular music studies as a discipline, but from the researchers' own direct and often deeply personal engagement with the performers, their communities, and their efforts to engage with wider society. This is further reflected in ethnographic processes of engagement with Indigenous musicians, built on relationships of trust and reciprocity in which the agency and authority of Indigenous musicians and culture bearers is paramount.

\section{Popular Music in Migrant Communities}

Both Australia and New Zealand have rich histories of immigration and multicultural contemporary societies. While their policies and procedures governing migration and multiculturalism differ (see Bendrups 2010), the characteristics surrounding minority migrant community participation in music are quite similar. Overwhelmingly, migrant minorities and their descendants engage in music for the purpose of establishing and maintaining a sense of cultural identity in the post-migratory landscape, and as a means of engaging with other sectors of society. I have previously referred to these practices as constructs of 'commemorative identity' and 'expressive identity' (Bendrups 2010: 34-37). Popular musics (of various sorts) play key roles in both of these processes. On the one hand, certain homeland traditions, such as samba drumming (Courteau 2008), are cast as 'popular' in the Australasian context. On the other hand, engagement in popular music production processes can provide a vehicle for any type of music, as demonstrated by the experience of Indonesian students in Melbourne (Scott-Maxwell 2008b). Historically, Some migrants have worked as novelty entertainers in popular music contexts (see Whiteoak 2008), while others form part of contemporary popular music scenes, as is the case for some Latin American performers (see Bendrups 2011).

Migrant musics have had a particularly important place within ethnomusicology on a global level as well as a local one ever since the 1970s turn towards 'urban' ethnomusicology (Manuel 1995). This has implications for popular music studies, as I have previously commented:

With the development of concepts such as insider- and auto-ethnography, and micromusic, ethnomusicology changed from its original conceptualisation as a field concerned with the music of "others" into a discipline capable of illuminating all musics through ethnographic research. This paradigm shift has facilitated the alignment of ethnomusicology and popular music studies in the last decade, as these two areas increasingly overlap in their relevance to the understanding of the global post-modern condition. It has also informed the way in which ethnomusicological frameworks have been applied to understanding the music cultures of immigrants in developed countries and metropolitan contexts. (Bendrups 2010: 32)

The notion of popular extends to public events such as festivals, as described by Johnson and Figgins (2005), Brunt (2010) and others, where ethnographic engagement with migrant communities by ethnomusicologists strongly informs the discourse of popular music studies. 


\section{Popular Music and the Pacific Region}

An Antipodean reality not really shared by other 'Anglosphere' nations is the interconnectedness between Australasia and Oceania. For New Zealand in particular, Oceania is a site of constant cultural engagement, effected and affected by the hundreds of thousands of Pacific Islander migrants who call New Zealand home, and by historical cultural and colonial ties. Australia similarly maintains economic and diplomatic interests in the Pacific, but arguably with lesser cultural engagement than New Zealand. The impact of Pacific Islanders on global popular music is a matter often ignored, but not insubstantial. The incorporation of Hawai'i into the USA enabled nearly a century of Polynesian or neo-Polynesian representation in US popular culture, and by extension, the world. It is no coincidence then that a particularly strong cohort of ethnomusicologists has emerged from the University of Hawai'i, reflecting a regional interest in the Pacific. A similar process applies to Australasia, where ethnomusicologists have been engaging with Pacific musics since the 1960s.

A great deal of ethnomusicological work in the Pacific - a region filled with multiple small islands often with small populations - is concerned with cultural documentation and preservation. Small Pacific island cultures are often perceived to be endangered by imported or colonial cultural products and tourism influences, leading to the preferencing of performances of tourist-friendly popular music, once referred to by Adrienne Kaeppler as 'airport art music' (1980: 135). However, since the 1980s, it has been increasingly observed that Pacific Islanders often use popular music elements for the purposes of cultural preservation. Allan Thomas' 1981 article was amongst the first to deconstruct this issue, arguing that the 'Cheap and Tawdry Borrowed Tunes' performed by Pacific Islanders for tourists might actually be serving a more crucial cultural function. This perspective was echoed by various Pacific scholars in the 1990s, leading towards a greater appreciation for the notion of 'adaptation' over 'acculturation' in Pacific post-colonial cultural discourses. As articulated by University of Hawaii ethnomusicologist Jane Moulin: "Considering the length of accelerated contact in Polynesia and the substantial amount of external pressure brought to bear on Indigenous music, people should stand in awe of its continuity, tenacity, and amazing adaptability instead of shaking their heads over loss or change" (1996: 140).

Moulin's perspective is almost universally shared by the current generation of Pacific music scholars in Australia and New Zealand, and this is reflected in the nature of their work. Macquarie University's Denis Crowdy, for example, has investigated guitar-based stringband (Crowdy 2005) and urban jazz-fusion in Papua New Guinea, and devoted a decade to developing the study of the Melanesian music industry. ${ }^{10}$ Dunedin-based Oliver Wilson's recent PhD examined the popular recording studios of Port Moresby as sites of connection to musicians' home villages, and of their music as a means of representing their connection to ples ('place' or 'home'). While directing the DCMS at Macquarie University, Phil Hayward examined the contemporary music cultures of some of the Pacific's smallest or most isolated communities, and, via the DCMS record label Coral Music, offered local musicians the opportunity to record and produce CDs. My own extensive work on Rapanui (Easter Island) has largely been concerned with explaining how contemporary musicians engage in popular music as a means of connecting to and maintaining aspects of Indigenous cultural heritage (see Bendrups 2009, 2006).

In all of these cases, the popular music focus of the researchers is a product of cultural processes already underway throughout the Pacific Islands, and thus reflects the contemporary reality of local musicians' musical lives. The quantity of scholarship conducted on the Pacific in Australia and New Zealand is in turn a product of colonial history and geographic coincidence. Where northern hemisphere colleagues might view the Pacific as a distant place, it is part of our culture-scape, and difficult to ignore. 


\section{Conclusion}

Returning to Tagg's characterisations of the challenges facing popular music studies in the twenty-first century, it is reasonable to say that they also apply to the Australasian context, as much as any other 'Western' context. The discipline of popular music studies in Australasia is marked by inherent interdisciplinarity, arguments about contextual and theoretical scope, and limitations in terms of engagement with modes of representation beyond or outside social theory and score-based paradigms. This said, I maintain that an Australasian 'voice' does exist in popular music studies, reflected in the persistent and substantial contribution of ethnomusicology to this field. This, in turn, is a reflection of the extent to which music researchers in Australia and New Zealand engage with Indigenous and multicultural musics. Locally, despite occasional tensions, ethnomusicology and popular music studies are now able to operate relatively unburdened by the ingrained divisions that have been observed in Euro-American musicology, ethnomusicology and popular music studies, and the broader field of Australasian music research is stronger for this. It is increasingly the case that popular music research in Australasia is facilitated by some sort of ethnographic method, and that the researchers are themselves engaged in some way with the communities of practice that feature in their studies.

\section{Endnotes}

${ }^{1}$ There are many similarities and connections between scholarship and scholarly institutions in Australia and New Zealand, but there are also quite a few differences, as well as (real and perceived) hegemonic tensions in the relationship between these two countries, which have vastly different population and economic bases. While popular music studies is not necessarily a unified phenomenon across both countries, the circumstances under which popular music studies is fostered are similar, and the IASPM-ANZ branch has been successful in uniting researchers from both countries. It is perhaps through IASPM-ANZ that a coherent community of scholarship is most obviously perceived, though there are also popular music scholars in Australasia who do not belong to this society. One important difference between New Zealand and Australia for the context of this article is that government policies towards Indigenous and migrant peoples are quite different, and this has some ramifications for how Indigenous and migrant cultural practices are formally contextualised. This is a matter that I have interrogated in a prior publication (see Bendrups 2010).

${ }^{2}$ For the purposes of this article, Indigenous culture refers to the cultural practices of New Zealand Māori, Australian Aboriginal, Torres Strait Islander and other Indigenous peoples of Micronesia, Melanesia, Polynesia and South-East Asia.

${ }^{3}$ For the purposes of this article, ethnomusicology refers to approaches to music that are grounded in ethnographic methodologies, and which often include 'multi-ethnic and multicultural' discussions of identity (Scott-Maxwell 2008a: 74). This may include the work of some scholars who don't self-identify as ethnomusicologists, but whose work has been conducted in ethnographic frameworks, or that aligns clearly with broader ethnomusicological practices and processes, and may exclude studies concerned with 'world' music that are not ethnographic in nature.

${ }^{4}$ Between 1995 and 2005, popular music became an integral course of study, and in some cases a defined disciplinary entity, at Griffith University, Southern Cross University, Macquarie University, University of Western Sydney, University of Auckland, and University of Otago, amongst other places. At Otago, the introduction of popular music studies probably saved the department of music from financial hardship. Currently, at the Queensland Conservatorium, Griffith University, the popular music cohort accounts for more than a quarter of the entire student body.

${ }^{5}$ In Australia, it is the 'young' universities (created in the 1960s) that have most enthusiastically embraced popular music studies. This said, most university music departments have at least one scholar working in popular music, even if not specifically described as such.

${ }^{6}$ Much like Smith (2011: 125) I stress that this article is not an exercise in completism. It presents interpretations grounded in my own experience as one of few ethnomusicologists to 
have worked at institutions in both New Zealand and Australia, and it quite necessarily draws contextually from my own direct institutional experiences. As such, I acknowledge that omissions and disagreements are inevitable, and where these occur, I hope that this article might provide a catalyst for further scholarly discussion.

${ }^{7}$ See http://www.auckland.ac.nz/uoa/home/about/departments-and-schools/department-ofanthropology/about-anthropology.

8 Taken from Bloustein (1999), Crowdy, Homan and Mitchell (2001), Collinson and Evans (2007), Bendrups (2008), Strong and Phillipov (2009), Brunt and Zemke (2010) and Cattermole, Homan and Smith (2011). This table is based on published refereed proceedings from IASPM-ANZ conferences, and does not include papers that might have been presented but not published.

${ }^{9}$ See:

http://www.mq.edu.au/about us/faculties and departments/faculty of arts/department of me dia music communication and cultural studies/about mmccs/.

${ }^{10}$ See: www.melanesianmusic.org.

\section{References}

Bartleet, Brydie-Leigh (2012) Stories of reconciliation: Building cross-cultural collaborations between Indigenous musicians and undergraduate music students in Tennant Creek. Australian Journal of Music Education 2: 11-21.

Bendrups, Dan-

(2011) Latin Down Under: Latin American Migrant Music in Australia and New Zealand. Popular Music 30 (2): 191-207.

(2010) Migrant Music in New Zealand: Issues and Concepts. In Henry Johnson Ed. Many Voices: Music and National Identity in Aotearoa/New Zealand. Newcastle: Cambridge Scholars Press: 30-38.

Ed. (2008) Music on the Edge: Selected Papers from the 2007 IASPM-ANZ Conference. Dunedin: IASPM-ANZ.

(2009) Navegando, Navegando: Easter Island Fusion and Cultural Performance. The Asia Pacific Journal of Anthropology 10 (2): 115-128.

(2006) War in Rapanui Music: A History of Cultural Representation. Yearbook for Traditional Music 38: 18-32.

Bloustien, Gerry Ed. (1999) Musical Visions: Selected Proceedings from $6^{\text {th }}$ National Australia/New Zealand IASPM and Inaugural Arnhem Land Performance Conference. Kent Town: Wakefield Press.

Breen, Marcus Ed. (1989) Our Place, Our Music: Aboriginal Music: Australian Popular Music in Perspective. Canberra: Aboriginal Studies Press.

Brunt, Shelley (2010) Sounding out the Streets: Performance, Cultural Identity and Place in Wellington's Cuba Street Carnival. In Henry Johnson Ed. Many Voices: Aotearoa/New Zealand Music and National Identity. Newcastle: Cambridge Scholars Press: $39-49$.

Brunt, Shelley and Zemke, Kirsten Eds. (2010) What's it Worth?: 'Value' and Popular Music - Selected Papers from the 2009 IASPM Australia New Zealand Conference. Auckland: IASPM-ANZ.

Jennifer Cattermole et al. Eds. (2011) Instruments of Change: IASPM Australia-New Zealand Conference Proceedings, 24-26 November 2010. Melbourne: Monash University School of English, Communication and Performance Studies.

Collinson, lan and Evans, Mark Eds. (2007) Sounds and Selves: Selected Proceedings from the 2005 IASPM Australia/New Zealand Conference. Sydney: IASPM-ANZ and Perfect Beat Publications. 
Corn, Aaron (2002) Dreamtime Wisdom, Modern-Time Vision: Tradition and Innovation in the Popular Band Movement of Arnhem Land, Australia. PhD dissertation, University of Melbourne.

Courteau, Mona-Lynn (2008) Mixed Messages: Re-performing Brazil in a New Zealand context. In Dan Bendrups Ed. Music on the Edge: Selected Papers from the 2007 IASPM-ANZ Conference. Dunedin: IASPM-ANZ: 57-61.

Crowdy, Denis (2005) Guitar Style, Open Tunings, and Stringband Music in Papua New Guinea. Apwitihire: Studies in Papua New Guinea Musics, no. 9, Port Moresby: Institute of Papua New Guinea Studies.

Denis Crowdy et al. Eds. (2001) Musical In-between-ness: The Proceedings of the $8^{\text {th }}$ IASPM Australia-New Zealand Conference 2001. Sydney: IASPM-ANZ.

De Wilde, Craig (2000) Popular Music Research and the "Music Academy": To Be or Not To Be. Paper presented at the 2000 conference of IASPM-ANZ, Sydney.

Downes, Graeme (2011) Songwriting Process in the Verlaines' album Corporate Moronic. In Dan Bendrups and Graeme Downes Eds. Dunedin Soundings: Place and Performance. Dunedin: University of Otago Press: 43-56.

Dunbar-Hall, Peter (2001) Research Methods and Aboriginal Songs from the Kimberley: A case Study. In Crowdy, Denis, Homan, Shane, and Mitchell, Tony Eds. Musical In-between-ness: The Proceedings of the $8^{\text {th }}$ IASPM Australia-New Zealand Conference 2001. Sydney: IASPM-ANZ: 28-34.

Hayward, Philip-

(2007) Mortal Motivations: Reflections on 15 Years of Perfect Beat (1992-2007). Perfect Beat 8 (2): 3-13.

(2012) Personal Communication, 7 September.

(2000) Riding the Rhythm: A short survey and critique of Australian Popular Music Studies and its relationship to mainstream Ethno-/Musicology. Musicology Australia 23: 176-186.

Johnson, Bruce Ed. (2007) Fifteenth Anniversary Forum. Perfect Beat 8 (2): 14-43.

Johnson, Henry and Figgins, Guil (2005) Diwali Downunder: Transforming and Performing Indian Tradition in Aotearoa/New Zealand. New Zealand Journal of Media Studies 9 (1): 25-35.

Kaeppler, Adrienne (1980) Polynesian Music and Dance. In Elizabeth May ed. Musics of Many Cultures: An Introduction. Berkeley: University of California Press.

Kartomi, Margaret-

(1984) Musicological Research in Australia 1979-1984. Acta Musicologica 56 (2): 109-145.

(1981) The Processes and Results of Musical Culture Contact: A Discussion of Terminology and Concepts. Ethnomusicology 25 (2): 227-249.

Loza, Steven (2006) Challenges to the Euroamericentric Ethnomusicological Canon: Alternatives for Graduate Reading, Theory and Method. Ethnomusicology 50 (2): 360-371.

Lysloff, René and Gay, Leslie (2003) Music and Technoculture. Hannover (NH): Wesleyan.

Manuel, Peter (1995) New Perspectives in American Ethnomusicology. TRANSTranscultural Music Review 1, http://www.sibetrans.com/trans/trans1/manuel.htm

Marett, Allan (2008) William Evans Visiting Fellow lecture, University of Otago, Dunedin, New Zealand, 7 October. 
McLean, Mervyn (1999) Weavers of Song: Polynesian Music and Dance. Auckland: Auckland University Press.

Merriam, Allan P. (1964) The Anthropology of Music. Evanston: Northwestern University Press.

Mitchell, Tony (1996) Popular Music and Local Identity: Rock, Pop and Rap in Europe and Oceania. London: Leicester University Press.

Moulin, Jane (1996) What's mine is yours? Cultural borrowing in a Pacific context. The Contemporary Pacific 8 (1): 128-153.

Neuenfeldt, Karl-

Ed. (2007) Indigenous Peoples, Recording Techniques and Recording Industry, The World of Music 49 (1).

Ed. (1997) The Didjeridu: From Arnhem Land to Internet. Sydney: John Libbey \& Co.

Ottosson, Åse-

(2010) Aboriginal Music and Passion: Interculturality and Difference in Australian Desert Towns. Ethnos: Journal of Anthropology 75 (3): 275-300.

(2009) Playing with Others and Selves: Australian Aboriginal Desert Musicians on

Tour. The Asia Pacific Journal of Anthropology 10 (2): 98-114.

Pearson, Sarina (2004) Pasifik/NZ Frontiers: New Zealand-Samoan Hip Hop, Music Video, and Diasporic Space. Perfect Beat 6 (4): 55-66.

Platt, Peter (2000) Only Connect. Musicology Australia 23: 3-18.

Ryan, Robyn (2002) Three-in-one or one-in-three? Sydney 2000 and the in-betweenness of Popular Music Studies, Musicology and Ethnomusicology. In Denis Crowdy et al. Eds. Musical In-between-ness: The Proceedings of the $8^{\text {th }}$ IASPM AustraliaNew Zealand Conference 2001. Sydney: IASPM-ANZ.

Scott-Maxwell, Aline-

(2008a) Localising Global Sounds: World Music and Multicultural Influences in Australia. In Shane Homan and Tony Mitchell Eds. Sounds of then, Sounds of Now: Popular Music in Australia. Hobart: ACYS Publishing: 73-92.

(2008b) Making Music to Feel at Home: The Indonesian student music scene in Melbourne, in Dan Bendrups Ed. Music on the Edge: Selected Papers from the 2007 IASPM-ANZ Conference. Dunedin: IASPM-ANZ: 149-154.

Smith, Graeme (2011) Popular Music Studies in Australia: Socio-Musical Activism and Institutionalisation. In Jennifer Cattermole et al. Eds. Instruments of Change: IASPM Australia-New Zealand Conference Proceedings, 24-26 November 2010. Melbourne: Monash University School of English, Communication and Performance Studies: 125-130.

Strong, Catharine and Phillipov, Michelle Eds. (2009) Stuck in the Middle: The Mainstream and Its Discontents Selected Proceedings of the 2008 IASPM-ANZ Conference, Brisbane. Auckland: IASPM-ANZ.

Tagg, Philip (2011) Caught on the Back Foot: Epistemic Inertia and Visible Music. IASPM@Journal 2 (1-2): 3-18.

Thomas, Allan (1981) The Study of Acculturated Music in Oceania: "Cheap and Tawdry Borrowed Tunes"? Journal of the Polynesian Society 90 (2): 183-191.

Whiteoak, John (2008) "Play Gypsy to Me": Australian imaginings of "Gypsies" in popular music before multiculturalism and "world music". In lan Collinson Ed. Whose Popular Music? Industry, Performers, Fans: Selected Proceedings from the 2006 IASPM Australia/New Zealand Conference. Sydney, IASPM-ANZ: 16-25. 
Wild, Stephen (2006) Ethnomusicology down under: a distinctive voice in the antipodes? Ethnomusicology 50 (2): 345-352.

Zemke-White, Kirsten (2002) Keeping It Real (Indigenous): Hip Hop in Aotearoa as Community, Culture, and Consciousness. In Claudia Bell and Steve Matthewman Eds. Cultural Studies in Aotearoa New Zealand: Identity, Space and Place. Oxford: Oxford University Press: 205-228. 